\title{
INFLUENCE OF DIFFERENT TYPES OF DIETS ON THE GROWTH PERFORMANCE OF JUVENILE GUPPIES (Poecilia reticulata Peters, 1859)
}

\author{
Abdul Khader Sultan Mohideen A $\mathbf{K}^{\mathbf{1}^{*}}$, Kareem Altaff $\mathbf{K}^{\mathbf{2}}$ \\ ${ }^{1}$ Department of Zoology, The New College (Autonomous), 147, Peters Road, \\ Affiliated to University of Madras, Chennai-600014, Tamil Nadu, India \\ *Email: smdbio@yahoo.co.in \\ ${ }^{2}$ Department of Marine Biotechnology, AMET (Deemed to be University), 135, SH 49, \\ Kanathur-603112, Tamil Nadu, India
}

Doi: 10.31943/mangiferaedu.v5i2.105

Received: May 8, $2020 \quad$ Accepted: July 25, $2020 \quad$ Published: July 31, 2020

Citation: Mohideen, A. K. S., Altaff, K. (2021). Influence of Different Types of Diets on The Growth Performance of Juvenile Guppies (Poecilia reticulata peters, 1859). Jurnal Mangifera Edu, 5(2), 93-102.

\begin{abstract}
This investigation aimed to analyze the effects of different diets and determine the optimal feed on the growth performance of guppy Poecilia reticulata (Peters, 1859). In the present study, juvenile guppies were procured from commercial fish breeders, Kolathur, Chennai, and fed with four experimental diets, namely Diet I (Control-Pellet feed), Diet II (Formulated feed), Diet III (Dry Tubifex), and Diet IV (Live feed Brachionus plicatilis) to examine the effects on growth and survival rates. In the experiment, 12 glass circular tanks with a volume of $10 \mathrm{~L}$ were used, and ten juveniles having an average body length and weight of $0.8 \mathrm{~cm}$ and $0.01 \mathrm{~g}$ were randomly introduced into each aquarium $(80 \mathrm{~cm} \times 30 \mathrm{~cm} \times 35 \mathrm{~cm})$ in triplicates. During the experimental study, the fish were fed two times a day ad libitum for 90 days. The various growth parameters and proximate composition of the diets were calculated by following standard methods. The findings showed significant differences $(p<0.05)$ in the fish's various growth parameters fed with different diets. The fish fed with Diet IV 52\% crude protein performed better than those provided with lower levels. The increase in growth parameters could be attributed to increased levels of dietary crude protein. However, the diet does not have any significant impact on fish survival rates. Thus, it is concluded that the Live Feed B. plicatilis with 52\% crude protein is suitable for the optimum growth of Poecilia reticulata under the current experimental set-up and recommended for feeding juvenile guppies.
\end{abstract}

Keywords: Brachionus plicatilis, Guppy fish, Live feed, Poecilia reticulata, Rotifer

\section{INTRODUCTION}

Ornamental fish production is an integral part of the aquaculture industry. It contributes immensely to rural development in most developing countries, and in leading markets, for aquarium fish, the retail value is several times that of its trade value, with a tremendous impact throughout the value-chain (Monticini, 2010). The global ornamental fish industry and accessories are worth $\$ 15$ billion, and over 2 billion live ornamental fish are traded annually, while India exported ornamental fish worth \$ 1.26 million, about 0.3 
percent of world trade in 2010-11 (Nair, 2012). However, India's export capacity is valued at \$ 30 million, or 100 crores per annum. Besides being geared towards exports, ornamental fish dominate the market at home and abroad for a seller. India's gross domestic ornamental fish trade is reported to be close to 15 crores (Swain, 2012).

Ornamental fish trade is a foreign exchange earner and provides tremendous openings to backyard and cottage industries with a significant role in the economy of developed and developing countries such as India (Mandal et al., 2007). Nevertheless, nutritional, health, and water quality issues in ornamental fish breeding need to be tackled to improve production (Ghosh et al., 2003). However, ornamental fish farming can be turned into an economically viable enterprise by developing techniques such as raceways, recirculation systems, biofiltration, and biosafety technologies. India's tropical climate, rich and diverse water resources provide the ideal conditions for the growth, maturation, and reproduction of ornamental fish. The freshwater ornamental fish species that dominate the trade are primarily from the Poecilidae, Characidae, Cyprinidae, and Cichlidae families because of their fast growth, conspicuous coloration, and market value (Kaur \& Shah, 2017).

The guppy Poecilia reticulata Peters 1859 is a Poeciliid fresh and brackish water ovoviviparous fish native to Trinidad, Venezuela, Barbados, Guyana, Northeast Brazil. It is one of the best-known ornamental fish used as an animal model to study ecology, evolution, developmental biology, genetics, and functional genomics. Male guppies are brilliantly colored with tremendous color variations compared to females. Vibrant male colors are a secondary sexual feature prominent and expressed as streaks, speckles, and lines of various pigmented colors with shades of black, white, red-orange, yellow, and green, whereas females do not show such coloration on their bodies (Figures $1 \& 2$ ). Female guppies show preferences for male pigmentation types such as orange, black, and distinct colored spots (Houde, 2019). However, the variation in male color patterns is due to the mutations in Kita and Csf1ra orthologs (Kottler et al., 2013).

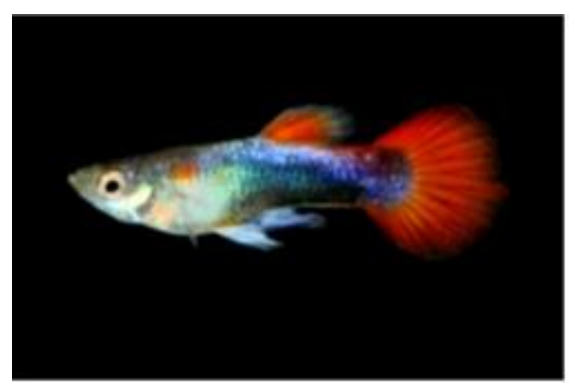

Figure 1. Male guppy Poecilia reticulata exhibiting conspicuous body pigmentation 


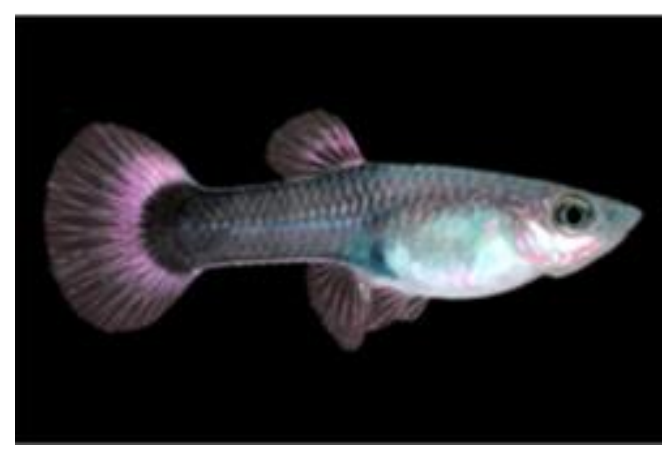

Figure 2. Female guppy Poecilia reticulata showing lack of body coloration

One of the most critical criteria that scientists face today in the larval rearing of fish is the change from endogenous to exogenous feeding by the fish larvae. Most of the fish larvae are unable to assimilate artificial foods during the initial stages of feeding. Hence, they depend on live food such as Rotifers, Artemia, and Copepods (Conceição et al., 2010). The rotifers belonging to the genus Brachionus have potential applications in larviculture because of their wide range in body size and better nutritive value (Hagiwara et al., 2017). The use of B. plicalitis species complex related to the mouth gape of fish larvae is administered up to 10 to 20 days of first feeding (Mills et al., 2017). After that, the other live feeds, such as Moina, are widely used to feed juvenile fishes in the ornamental fish culture (Das et al., 2012).

Therefore, it is imperative to understand the nutritional demands in aquarium fish species to improve productivity (Velasco-Santamaría \& Corredor-Santamaría, 2011). Tubifex is a tremendous source of food for cultured fish species. The uses of Tubifex as a feed for aquarium fishes have been reported in several studies. The fantail guppy Poecilia reticulata fed with living Tubifex attained optimal growth performance compared to commercial feed (Banani et al., 2010).

The present study is an attempt to investigate the efficacy of different types of feed on the growth parameters of P. reticulata and to optimize the larval rearing conditions with emphasis on suitable feed.

\section{RESEARCH METHOD}

The live-bearing ornamental juvenile guppies Poecilia reticulata were procured from commercial fish breeders of Kolathur (Chennai, Tamil Nadu, India). The experiments were carried out for 90 days in triplicates in the Unit of Live Feed and Reproductive Biology Laboratory, The New College, Chennai. The juvenile guppies were shifted to rearing tanks and disinfected with $0.005 \mathrm{~g} / \mathrm{L}$ of potassium permanganate solution (Qualigens) for $15 \mathrm{~min}$ and transferred to circular 500 L FRP tanks containing filtered tube well water. They were 
Jurnal Mangifera Edu, Volume 5, Nomor 1, Juli 2020, 93-102

acclimatized for ten days with aeration under laboratory conditions. The fishes were fed with commercial pellet feed (Taiyo pet products, Kolathur, Chennai) ad libitum in two divided doses.

In the experiment, 12 aquarium tanks $(30 \times 40 \times 50 \mathrm{~cm})$ were used, and ten juvenile guppies for each aquarium were put in. The different water quality parameters like temperature, dissolved oxygen, and $\mathrm{pH}$ were observed every two days. The air diffuser increases the oxygen level by up to $9 \mathrm{mg}$ L-1. Fish feed is given twice a day on an ad libitum basis. Manure and uneaten feed is removed between 9:00 am and 05.00 pm from the bottom of each container. Every day $10 \%$ of the water in each experimental tank was exchanged for a new one. Fish length and weight were documented over the ages of 10, 20, 30, 40, 50, 60, 70,80 , and 90 days from the start of the experiment. The total length $(\mathrm{cm})$ of each fish was measured using a metric scale from the snout tip to the caudal fin's extended tip. After blotdrying excess water from the body, each fish's weight $(\mathrm{g})$ was taken to the nearest gram using a digital monopan electronic balance. The experiments were carried out in triplicates under similar environmental conditions (Dernekbasi et al., 2010).

The trials were conducted to study the effects of the dietary treatments using Diet I (Control) - Commercial pellet feed (Taiyo fish products), Diet II - Formulated feed (Table 1), Diet III - Dry Tubifex (Taiyo fish products), Diet IV - Live feed (B. plicatilis) on the growth and survival of guppies. Mean length, weight, specific growth rate (SGR), condition factor $(\mathrm{CF})$, and survival were determined. The four diets tested proximate compositions were analyzed for crude protein, crude lipid, crude fiber, and ash content, using standard methods (AOAC, 2000) to verify nutrient levels.

Table 1. Composition of different ingredients of the formulated feed

\begin{tabular}{ccc}
\hline Sl. No. & Ingredients & $\begin{array}{c}\text { Contents } \\
\text { (g/kg dry weight) }\end{array}$ \\
\hline 1 & Fish meal & 50 \\
2 & Shrimp meal & 30 \\
3 & Soy flour & 50 \\
4 & Corn flour & 60 \\
5 & Sago & 60 \\
6 & Vitamin & 5 \\
7 & Spirulina & 1 \\
\hline
\end{tabular}


Jurnal Mangifera Edu, Volume 5, Nomor 1, Juli 2020, 93-102

Fish growth performance was determined by using the following formula 1, 2, and 3 .

Formula 1. Specific growth rate $(\mathrm{SGR})=\frac{\operatorname{In} W t-\operatorname{In} W 0}{t} \times 100$

Formula 2. Condition factor $(\mathrm{CF})=W / L^{3} \times 100$

Formula 3. Survival $=\frac{N t}{N 0} \times 100$

Note:

Wt and Wo are final and initial fish weights $(\mathrm{g})$

$\mathrm{Nt}$ and No are the final and initial fish numbers for each replicate $t$ is the experimental duration in days

$\mathrm{L}$ is the fish length

The data collected from the experiment analyzed with the help of a one-way analysis of variance (ANOVA) using SPSS Version 10.0 program to find the efficacy between the three types of feed. ANOVA revealed significant differences among groups, and hence multiple comparison tests were performed among the means using Tukey's test. The statistically significant differences were calculated by setting the aggregate type I error at $5 \%(\mathrm{p}<0.05)$.

\section{RESULTS AND DISCUSSION}

The proximate composition in terms of their protein content, lipid, etc., was found to be in the following sequence Diet IV > Diet II > Diet III > Diet I (Table 2).

Table 2. Proximate composition of four experimental diets

\begin{tabular}{ccccc}
\hline Composition & $\begin{array}{c}\text { Diet I } \\
\text { Control }\end{array}$ & $\begin{array}{c}\text { Diet II } \\
\text { Formulated } \\
\text { Feed }\end{array}$ & $\begin{array}{c}\text { Diet III } \\
\text { Dry } \\
\text { Tubifex }\end{array}$ & $\begin{array}{c}\text { Diet IV } \\
\text { B. plicatilis }\end{array}$ \\
\hline $\begin{array}{c}\text { Crude Protein } \\
\text { g. Kg }\end{array}$ & $38.2 \pm 0.2^{\mathrm{a}}$ & $46.1 \pm 0.1^{\mathrm{c}}$ & $42.3 \pm 0.1^{\mathrm{b}}$ & $52.2 \pm 0.1^{\mathrm{d}}$ \\
$\begin{array}{c}\text { Crude Lipid } \\
\mathrm{g} \cdot \mathrm{Kg}^{-1}\end{array}$ & $3.1 \pm 0.1^{\mathrm{a}}$ & $8.2 \pm 0.2^{\mathrm{b}}$ & $3.2 \pm 0.1^{\mathrm{a}}$ & $9.2 \pm 0.2^{\mathrm{c}}$ \\
$\begin{array}{c}\text { Crude Fibre } \\
\mathrm{g} \cdot \mathrm{Kg}^{-1}\end{array}$ & $6.2 \pm 0.2^{\mathrm{a}}$ & $7.2 \pm 0.2^{\mathrm{b}}$ & $8.2 \pm 0.1^{\mathrm{c}}$ & $7.1 \pm 0.2^{\mathrm{b}}$ \\
$\quad \mathrm{Ash}$ & $8.6 \pm 0.2^{\mathrm{c}}$ & $5.3 \pm 0.1^{\mathrm{a}}$ & $6.9 \pm 0.1^{\mathrm{b}}$ & $5.2 \pm 0.1^{\mathrm{a}}$ \\
$\begin{array}{c}\mathrm{g} \cdot \mathrm{Kg}^{-1} \\
\text { Moisture (\%) }\end{array}$ & $10.2 \pm 0.2^{\mathrm{c}}$ & $8.1 \pm 0.1^{\mathrm{a}}$ & $10.2 \pm 0.2^{\mathrm{c}}$ & $9.2 \pm 0.1^{\mathrm{b}}$ \\
\hline
\end{tabular}

Values (Mean \pm SD) with different superscripts in the same row are significantly different at the $5 \%$ level 
The different water quality parameters like temperature, dissolved oxygen, and $\mathrm{pH}$ were observed to be $28 \pm 2^{\circ} \mathrm{C}, 6.31 \pm 33 \mathrm{mg} / \mathrm{l}$, and $7-8$, respectively. The statistical analysis showed significant differences between the four experimental diets. The significance level was found to be below $\alpha$ value 0.05 .

The various growth parameters and survival rates in the guppy are represented in Table 3. Juvenile guppies fed with Diet IV (B. plicatilis) registered the best growth parameters and survival rate (97\%) compared to other diets. The highest SGR value was observed in Diet IV $(3.71 \pm 0.00 \% / d)$ that increased significantly with the level of dietary protein.

Table 3. Growth Performance and survival rate of Poecilia reticulata fed with different diets for 90 days

\begin{tabular}{ccccc}
\hline $\begin{array}{c}\text { Growth } \\
\text { Performance }\end{array}$ & $\begin{array}{c}\text { Diet I } \\
\text { Control }\end{array}$ & $\begin{array}{c}\text { Diet II } \\
\text { Formulated } \\
\text { Feed }\end{array}$ & $\begin{array}{c}\text { Diet III } \\
\text { Dry Tubifex }\end{array}$ & $\begin{array}{c}\text { Diet IV } \\
\text { B. plicatilis }\end{array}$ \\
\hline Initial Length (cm) & $0.8 \pm 0.05$ & $0.8 \pm 0.05$ & $0.8 \pm 0.05$ & $0.8 \pm 0.05$ \\
Final Length (cm) & $2.86 \pm 0.049^{\mathrm{a}}$ & $2.91 \pm 0.061^{\mathrm{b}}$ & $2.88 \pm 0.042^{\mathrm{ab}}$ & $3.00 \pm 0.113^{\mathrm{c}}$ \\
Initial Weight (g) & $0.01 \pm 0.00$ & $0.01 \pm 0.00$ & $0.01 \pm 0.00$ & $0.01 \pm 0.00$ \\
Final Weight (g) & $0.226 \pm 0.002^{\mathrm{a}}$ & $0.238 \pm 0.002^{\mathrm{c}}$ & $0.231 \pm 0.002^{\mathrm{b}}$ & $0.281 \pm 0.004^{\mathrm{d}}$ \\
SGR (\%) & $3.47 \pm 0.005^{\mathrm{a}}$ & $3.52 \pm 0.005^{\mathrm{c}}$ & $3.49 \pm 0.005^{\mathrm{b}}$ & $3.71 \pm 0.005^{\mathrm{d}}$ \\
Condition factor (CF) & $0.950 \pm 0.01^{\mathrm{a}}$ & $0.962 \pm 0.02^{\mathrm{a}}$ & $0.969 \pm 0.01^{\mathrm{a}}$ & $1.039 \pm 0.02^{\mathrm{b}}$ \\
Survival (\%) & $93.33 \pm 5.77^{\mathrm{a}}$ & $93 \pm 5.77^{\mathrm{a}}$ & $97 \pm 5.77^{\mathrm{a}}$ & $97 \pm 5.77^{\mathrm{a}}$ \\
\hline Values & & & &
\end{tabular}

Values (Mean \pm SD) with different superscripts in the same row are significantly different at the $5 \%$ level

The final mean length $(3.00 \pm 0.113 \mathrm{~cm})$ and weight $(0.281 \pm 0.004 \mathrm{~g})$ were highest in Diet IV than other diets. The enhanced growth performance of fish fed with live feed rotifer may be due to their small size, better nutrition, and feed acceptability, which agree with Ogata et al. (2011) studies. The rotifer diet's impact on pikeperch (Sander lucoperca) significantly improved pikeperch larvae's optimum survival rate (Yanes-Roca et al., 2018). According to Gopakumar et al. (2012) the fish larvae are typically attracted to live feed due to their movement and exhibit a preference for small-size prey concerning their mouth gape. However, the effective use of live feed mainly depends on its size and nutritional content. The role of $\mathrm{B}$. plicatilis species in the aquaculture sector is an essential factor in improving the quality of food supply and the growth of larviculture (Kim et al., 2018). Besides, experimental reports suggest that no single formulated artificial fish diet can provide better growth and survival rates than live feed despite advancements in fish feed technology. Thus, 
the higher growth efficiency in $P$. reticulata could be due to $52 \%$ crude protein and $9 \%$ crude lipid levels in the live feed rotifer.

The juvenile guppies fed with Diet II (Formulated feed) showed better growth parameters than Diet I and Diet III. The $46 \%$ crude protein content of the diet might have enhanced the bodyweight of guppies. Similarly, Mohanta \& Subramanian (2002) evaluated the growth performance of the goldfish Carassius auratus using four formulated against locally available commercial feeds. The weight increment with commercial feed was significant compared to formulated feeds ( $40 \%$ crude protein-based on chicken liver, mussel meal or squid meal, lean shrimp meal). Furthermore, when the zebrafish larvae fed with formulated diet from the initial stage onwards showed an increase in the total length size (Kaushik et al., 2011). However, the formulated feed did not impact zebrafish's growth aspects (Gonzales \& John, 2012).

Juvenile guppies fed with Diet III (Dry Tubifex) showed reduced growth parameters compared to Diet IV and Diet II. The decreased growth performance with Dry Tubifex may be due to the diet's nature that exhibits minimal feed variation, which conforms to the results observed in zebrafish fed dried Tubifex (Rabbane \& Rahman, 2017). Furthermore, the angelfish Pterohyllum scalare fed with dried Tubifex also showed lower growth performance than live food (Kasiri et al., 2012). In contrast, Görelşahin et al. (2018) established Tubifex's effects on the growth aspects of $P$ reticulata. Their results indicated improved productivity and increased growth efficiency only in females when compared to male guppies.

Lower growth performance was observed in Diet I (Pellet feed-control) when compared to other experimental diets. Similar results were observed in the larval rearing of koi carp C. carpio (Sarower-E-Mahfuj et al., 2012). The most striking disadvantages of the pellet feed are due to its size and sinking ability. However, most juvenile species may not consume the bigger pellets than their mouth size (Pandey, 2013). Nevertheless, zebrafish fed with commercial pellet feed was characterized by viable offsprings and better growth aspects under in vitro conditions (Rabbane \& Rahman, 2017). Eventually, lower growth and survival rates of larvae fed with the artificial diet could be due to inefficient use of artificial dry food in the first few weeks of life (Montchowui et al., 2008).

Condition factor (CF) was highest in Diet IV (1.039 \pm 0.02$)$ compared to other groups. The CF of Diet IV was found to be $1.039(>1)$, is an indication of better growth performance and good health condition of the juvenile guppies during the experimental period, which is following the length-weight relationship and condition factor observed in Botia Dario 
Jurnal Mangifera Edu, Volume 5, Nomor 1, Juli 2020, 93-102

(Haque \& Biswas, 2014) and the Nile tilapia fingerlings Oreochromis niloticus (Ighwela et al., 2011) indicating good health status and isometric growth.

\section{CONCLUSION}

This study has demonstrated that live feed B. plicatilis (52\% crude protein) has significantly influenced the various growth parameters and survival rate of juvenile guppies Poecilia reticulata. Moreover, it establishes the primacy of the live feed Rotifer over conventional formulated feed in promoting optimum growth and better health status of the guppies. Further studies related to ontogeny, organogenesis, and development would pave the way for adopting suitable and sustainable strategies to enhance and augment the ornamental fish culture and management.

\section{ACKNOWLEDGEMENTS}

The authors would like to thank the Management, Principal, and Head, PG \& Research Department of Zoology, The New College (Autonomous), Chennai, Tamil Nadu, India, for providing laboratory facilities, support, and encouragement.

\section{REFERENCES}

Banani, M., Arunava, M., \& Samir, B. (2010). Growth and Pigmentation Development Efficiencies in Fantail Guppy, Poecilia reticulata fed with Commercially Available Feeds. Agriculture and Biology Journal of North America, 1(6), 1264-1267.

Conceição, L. E. C., Yúfera, M., Makridis, P., Morais, S., \& Dinis, M. T. (2010). Live Feeds for Early Stages of Fish Rearing. Aquaculture Research, 41(5), 613-640.

Das, P., Mandal, S. C., Bhagabati, S. K., Akhtar, M. S., \& Singh, S. K. (2012). Important Live Food Organisms and Their Role in Aquaculture. Frontiers in Aquaculture, 5(4), 69-86.

Dernekbasi, S., Unal, H., Karayucel, I., \& Aral, O. (2010). Effect of Dietary Supplementation of Different Rates of Spirulina (Spirulina platensis) on Growth and Feed Conversion in Guppy (Poecilia reticulata Peters, 1860). Journal of Animal and Veterinary Advances, 9(9), 1395-1399.

Ghosh, A., Mahapatra, B. K., \& Datta, N. C. (2003). Ornamental Fish Farming-Successful Small Scale Aqua Business in India. Aquaculture Asia, 8(3), 14-16.

Gonzales, J., \& John, M. (2012). Preliminary Evaluation on the Effects of Feeds on the Growth and Early Reproductive Performance of Zebrafish (Danio rerio). Journal of the American Association for Laboratory Animal Science, 51(4), 412-417.

Gopakumar, G., Abdul Nazar, A. K., Tamilmani, G., Sakthivel, M., Kalidas, C., 
Jurnal Mangifera Edu, Volume 5, Nomor 1, Juli 2020, 93-102

Ramamoorthy, N., Palanichamy, S., Ashok Maharshi, V., Srinivasa Rao, K., \& Syda Rao, G. (2012). First Experience in the Larviculture of Cobia, Rachycentron canadum (Linnaeus, 1752) in India. Indian Journal of Fisheries, 59(1), 59-63.

Görelşahin, S., Yanar, M., \& Kumlu, M. (2018). The Effects of Stocking Density, Tubifex Feeding and Monosex culture on Growth Performance of Guppy (Poecilia reticulata) in a Closed Indoor Recirculation System. Aquaculture, 493, 153-157.

Hagiwara, A., Kim, H.-J., \& Marcial, H. (2017). Mass Culture and Preservation of Brachionus Plicatilis sp. Complex. In Rotifers (pp. 35-45). Springer.

Haque, S., \& Biswas, S. P. (2014). Length-Weight Relationship and Condition Factor of Botia dario (Hamilton-Buchanan) from Sivasagar District. International Journal of Fisheries and Aquatic Studies, 2(1), 244-247.

Houde, A. (2019). Sex, Color, and Mate Choice in guppies. Princeton University Press.

Ighwela, K. A., Ahmed, A. B., \& Abol-Munafi, A. B. (2011). Condition Factor as an Indicator of Growth and Feeding Intensity of Nile Tilapia Fingerlings ( Oreochromis niloticus ) Feed on Different Levels of Maltose. American-Eurasian J. Agric. \& Environ. Sci, 11(4), 559-563.

Kasiri, M., Farahi, A., \& Sudagar, M. (2012). Growth and Reproductive Performance by Different Feed Types in Fresh Water Angelfish (Pterophyllum scalare Schultze, 1823). Veterinary Research Forum, 3(3), 175.

Kaur, R., \& Shah, T. K. (2017). Role of Feed Additives in Pigmentation of Ornamental Fishes. International Journal of Fisheries and Aquatic Studies, 5(2), 684-686.

Kaushik, S., Georga, I., \& Koumoundouros, G. (2011). Growth and Body Composition of Zebrafish (Danio rerio) Larvae Fed a Compound Feed from First Feeding Onward: Toward Implications on Nutrient Requirements. Zebrafish, 8(2), 87-95.

Kim, H.-J., Lee, J.-S., \& Hagiwara, A. (2018). Phototactic Behavior of Live Food Rotifer Brachionus Plicatilis Species Complex and its Significance in Larviculture: a Review. Aquaculture, 497, 253-259.

Kottler, V. A., Fadeev, A., Weigel, D., \& Dreyer, C. (2013). Pigment Pattern Formation in the Guppy, Poecilia reticulata, Involves the Kita and Csflra Receptor Tyrosine Kinases. Genetics, 194(3), 631-646.

Mandal, S., Mahapatra, B. K., Tripathi, A. K., Verma, M. R., Datta, K. K., \& Ngachan, S. V. (2007). Agribusiness Opportunities of Ornamental Fisheries in North-Eastern Region of India. Agricultural Economics Research Review, 20(347-2016-16835), 471488.

Mills, S., Alcántara-Rodríguez, J. A., Ciros-Pérez, J., Gómez, A., Hagiwara, A., Galindo, K. H., Jersabek, C. D., Malekzadeh-Viayeh, R., Leasi, F., \& Lee, J.-S. (2017). Fifteen Species in One: Deciphering the Brachionus Plicatilis Species Complex (Rotifera, 
Jurnal Mangifera Edu, Volume 5, Nomor 1, Juli 2020, 93-102

Monogononta) through DNA Taxonomy. Hydrobiologia, 796(1), 39-58.

Mohanta, K. N., \& Subramanian, S. (2002). Effect of Diets with Protein from Different Sources on the Growth of Goldfish, Carassius auratus.

Montchowui, E., Lalèyè, P., Philippart, J. C., \& Poncin, P. (2008). A First Experiment of Rearing Larvae of the African Carp, Labeo parvus Boulenger, 1902 (Pisces: Cyprinidae) under Nursery Conditions. Book Abstracts, 32nd Annual Larval Fish Conference, Kiel-Germany.

Monticini, P. (2010). The Ornamental Fish Trade: Production and Commerce of Ornamental Fish: Technical-Managerial and Legislative Aspects.

Nair, L. (2012). Export of Ornamental Fishes and Developmental Interventions by MPEDA. Ornamentals Kerala, 57-60.

Ogata, Y., Tokue, Y., Yoshikawa, T., Hagiwara, A., \& Kurokura, H. (2011). A Laotian Strain of the Rotifer Brachionus angularis Holds Promise as a Food Source for SmallMouthed Larvae of Freshwater Fish in Aquaculture. Aquaculture, 312(1-4), 72-76.

Pandey, G. (2013). Feed Formulation and Feeding Technology for Fishes. International Research Journal of Pharmacy, 4(3), 23-30.

Rabbane, M. G., \& Rahman, M. R. (2017). Effects of Natural and Commercial Diets on growth, Reproductive Performances and Embryogenesis of Zebrafish Danio rerio. Dhaka University Journal of Biological Sciences, 26(2), 159-166.

Sarower-E-Mahfuj, M., Hossain, M. B., \& Minar, M. H. (2012). Biochemical Composition of an Endangered Fish, Labeo bata (Hamilton, 1822) from Bangladesh Waters. American Journal of Food Technology, 7(10), 633-641.

Swain, S. K. (2012). Freshwater Ornamental Fish Farming and Trade: A Roadmap for India. Souvenir, Ornamentals Kerala, 93-97.

Velasco-Santamaría, Y., \& Corredor-Santamaría, W. (2011). Nutritional Requirements of Freshwater Ornamental Fish: a Review. Revista MVZ Córdoba, 16(2), 2458-2469.

Yanes-Roca, C., Mráz, J., Born-Torrijos, A., Holzer, A. S., Imentai, A., \& Policar, T. (2018). Introduction of Rotifers (Brachionus plicatilis) during Pikeperch First Feeding. Aquaculture, 497, 260-268. 